Article

\title{
Bacterial Diversity in the Asphalt Concrete Lining of the Upper Water Reservoir of a Pumped-Storage Scheme
}

\author{
Miroslav Špano ${ }^{1}$, Jaromír Říha ${ }^{1}\left(\mathbb{D}\right.$, Alena Španová ${ }^{2}$, Ondrej Šedo ${ }^{3}$ and Bohuslav Rittich ${ }^{2, *(1)}$ \\ 1 Faculty of Civil Engineering, Brno University of Technology, Veveří 331, 60200 Brno, Czech Republic; \\ spano.m@fce.vutbr.cz (M.Š.); riha.j@fce.vutbr.cz (J.̌̌.) \\ 2 Faculty of Chemistry, Brno University of Technology, Purkyňova 118, 61200 Brno, Czech Republic; \\ spanovaale@gmail.com \\ 3 Central European Institute of Technology, Masaryk University, Kamenice 5, 62500 Brno, Czech Republic; \\ sedo@sci.muni.cz \\ * Correspondence: rttch@seznam.cz
}

Received: 31 July 2020; Accepted: 28 October 2020; Published: 30 October 2020

check for updates

\begin{abstract}
Asphalt concrete linings (ACLs) are frequently used in pumped-storage hydropower schemes with frequently oscillating reservoir water levels. ACLs can be damaged during operation, which shortens their service life. One type of damage is the formation of blisters. In this study, the bacterial diversity in damaged and undamaged portions of the ACL of an upper water reservoir was evaluated. Matrix-Assisted Laser Desorption/Ionization-Time of Flight Mass Spectrometry (MALDI-TOF MS) was employed for the identification of the bacterial strains. No bacteria were detected growing inside the undamaged dense layer. Low bacterial diversity ( 2 and 4 morphotypes) was found in the upper part that has no contact with the reservoir water and in the lowest part that is permanently under water, respectively. More complex bacterial diversity (16 morphotypes covered by 2 different genera and 4 species) was found on the mastic coating of the ACL, which was alternately under and above the water. Very complex bacterial compositions (53 morphotypes covered by at least 13 different species from 6 genera) were found in samples taken from open blisters. Bacterial genera that are known to utilize asphalt products as a source of nutrition were found in the open blisters. The results reflect the importance of bacterial diversity in blisters and their possible role in ACL degradation.
\end{abstract}

Keywords: pumped-storage hydropower plant; asphalt concrete lining; open blisters; bacterial diversity; MALDI-TOF MS

\section{Introduction}

Asphalt concrete linings (ACLs) have been used to seal the upstream slopes of dams for decades [1,2]. ACLs are frequently used in mountainous regions in high head pumped-storage hydropower schemes with frequently oscillating reservoir water levels. An ACL is typically composed of a transition screed layer spread on the upstream slope of a rockfill dam. This layer is overlaid by a drainage layer, a binder, a dense layer, and a mastic coating that protects the dense layer against ultraviolet radiation [2].

The usual service life of an ACL is approx. 30 years. However, sometimes the service life is shortened due to various types of damage to the lining, which sometimes may be quite extensive [3]. In the case of pumped-storage schemes, damage to the lining primarily occurs within the zone of water level fluctuation, where the asphalt surface is subject to frequent and significant temperature changes, which range from -15 to $+60{ }^{\circ} \mathrm{C}$ [4-6]. One type of local defect is the creation of local blisters, which can be of different sizes and shapes and which bulge during their development [5]. 
Such defects have been documented at, e.g., the Porabka and Žarnowiec reservoirs in Poland [7] and the Zhanghewan pumped-storage power station in China [5]. During investigations conducted by the authors, the same defects were also found at the Längental Dam in Austria and at the upper reservoir of the Markersbach pumped-storage plant in Germany. Knowledge of blister formation is important because the damage done to the ACL shortens its service life. The blisters that appear on the asphalt facing could be caused by a number of factors [5]. The causes of their origin and development have been discussed by experts for decades [2,5,7-9]. It is considered that they gradually develop for different reasons, which include the use of poor-quality construction materials [10] as well as unsuitable asphalt concrete production techniques [3] combined with the effects of extreme loads. The influence of climatic conditions on the mechanical characteristics of bitumens and stone mastic asphalts was studied by Teltayev et al. [11]. One opinion, which originates from highway engineering, is that the blisters are the result of the development of volatile gases or water vapour beneath the asphalt layers of the liner [5]. This development is exacerbated by significant increases in surface temperatures [4]. According to Wang et al. [5], blistering is caused by the vapour pressure formed by the water enclosed in the middle of the impervious layer in the presence of high temperatures. Croll [12] suggested that the creation of blisters is a result of the gradual growth of upward buckles induced by cyclic changes in stresses due to surface temperature fluctuations. According to the authors of [13], blister formation is caused by the expansion of water vapour due to the alternation of cold and warm seasons. Sobolewski [7] attributed the blister development inside upper dense layers to the use of high porosity aggregate or aggregates containing clayey components, supporting an increase in moisture inside such layers and producing local blisters.

The above mentioned papers were focused on blister formation from a physical (material) point of view. Despite numerous studies that have reported microbial utilisation of asphalt under both laboratory and natural conditions, little consideration has so far been given to microbial activity as a possible cause of asphalt pavement deterioration [14,15]. Many bacterial strains [16-22], yeasts [23], fungal, and algal strains [22,24], isolated from contaminated soils and from natural asphalt, have been shown to degrade asphalt and its fractions by exploiting carbon under aerobic and anaerobic conditions. The authors of [14] indicated that the development of blisters was mainly due to microbial activity in the asphalt. According to these authors, the gases produced by microorganisms dissolved into the asphalt overlay material exist in quantities sufficient to cause blistering.

We hypothesized that bacterial genera that utilise asphalt products as a source of nutrition may be involved in the subsequent degradation of the ACL in open blisters. For this reason, it is important to study their composition. The aim of this study was to compare bacterial diversity in undamaged and damaged ACLs (open blisters) and to discuss the potential role of bacteria in the process of blister and ACL degradation. Our study focused on the identification of live bacteria that degrade asphalt.

\section{Materials and Methods}

\subsection{Description of the Study Area and Blisters}

The studied upper water reservoir of the Dlouhe Strane pumped-storage hydropower plant is located in the northeast of the Czech Republic in the Jeseniky Mountains. The elevation of the reservoir is $1350 \mathrm{~m}$ above sea level. The climatic conditions at the site are severe: the average annual temperature is $+4{ }^{\circ} \mathrm{C}$; there are 160 days when the temperature is below zero; the average annual precipitation is $1200 \mathrm{~mm}$; and there are 160 days with snow cover, on average. The bottom and slopes of the reservoir are equipped with an asphalt concrete lining. The reservoir water level fluctuates according to the operating regime of the scheme (pumping and hydropower production). In the following text we distinguish between the lowest part of the slopes, which is permanently below the water level; the middle zone, which is exposed to water level fluctuations; and the upper part, which does not come into contact with the reservoir water. 
The lining is composed of layers in the manner shown in Figure 1. The dense asphaltic concrete (DAC) is about $80 \mathrm{~mm}$ thick, while the thickness of the underlying binder-a porous asphaltic concrete (PAC) layer-varies from 40 to $80 \mathrm{~mm}$. It is composed from greywacke aggregates connected with an asphalt binder, sand, and pulverized limestone filler. The drainage layer (200 $\mathrm{mm})$ lies upon the transition layer of the dam body. The upper face of the dense layer has been coated with an approx. $2 \mathrm{~mm}$-thick mastic layer composed of asphalt (30\%) and a limestone filler (70\%). An asphalt emulsion spray covers the drainage layer.

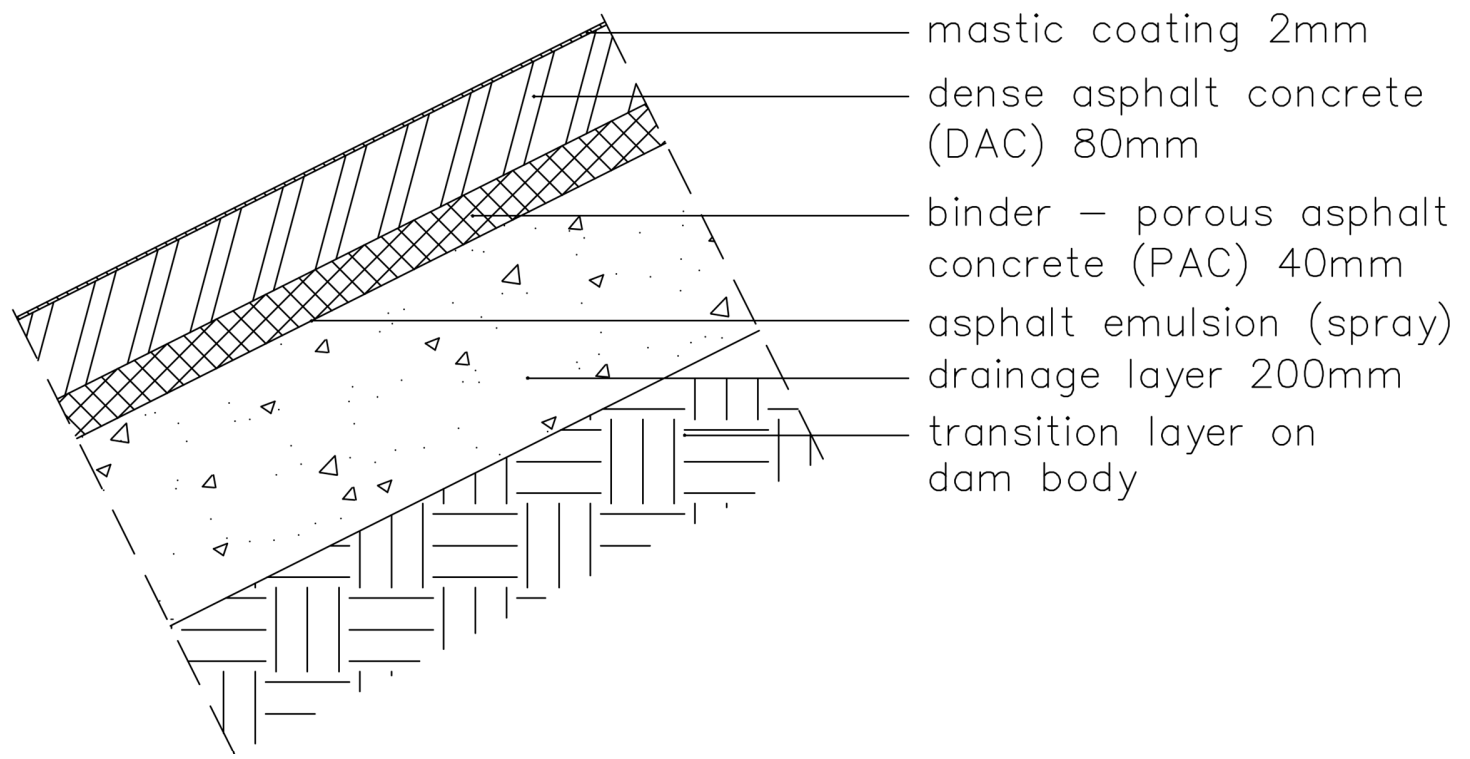

Figure 1. Cross section of the asphalt concrete lining.

The defects in the ACL were manifested by the creation of local closed and open blisters. Two of the studied open blisters looked like burst pustules with a diameter of around $150 \mathrm{~mm}$ and a height of between 30 and $50 \mathrm{~mm}$ with an open crack (Figure 2). Inside the blisters there was a cavity with a depth of between 30 and $80 \mathrm{~mm}$, which was filled with water and the crumbled components of the asphalt concrete (asphalt, asphalt with mastic remnants, and aggregates).

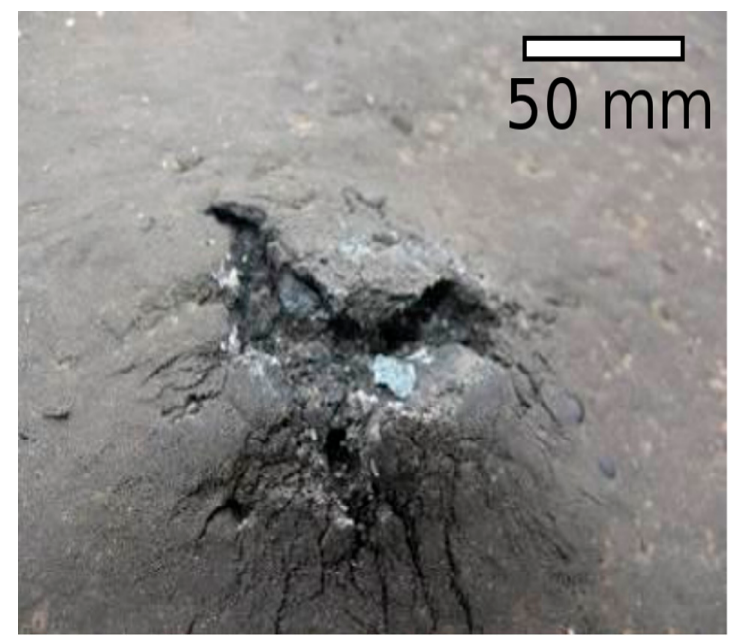

Figure 2. Photograph of an asphalt concrete lining (ACL) defect (the detail of an open blister). 


\subsection{Sampling Method and Sampling Points}

The conducted experiments were focused on the identification of bacteria isolated from the damaged open blisters and from the undamaged blister-free parts of the asphalt concrete lining. All of the samples analysed in this study were taken in April and May 2014, when the air temperature reached $26^{\circ} \mathrm{C}$. Many blisters appeared during this relatively warm year, which also featured a mild winter. The sampling points were chosen with the aim of covering both the areas with a large number of blisters and the non-damaged areas. Special attention was paid to the parts of the ACL that were without visible defects. Samples were taken from different elevations of the ACL (the upper part that has no contact with the reservoir water, the middle zone that is alternatively under and above the water, and the lowest part that is permanently under water), namely, at 1326, 1340, and $1349 \mathrm{~m}$ a.s.l. The samples from the open blisters were taken at an elevation of $1341 \mathrm{~m}$ a.s.l.

The following samples were taken for analysis:

- Water from the upper reservoir. The water samples from the reservoir were taken into sterile bottles;

- Water, asphalt, asphalt with mastic remnants, and crumbled aggregate from inside the openings of two fully developed blisters in the damaged ACL. The samples were taken in two replicates. The water from the open blisters was taken using a sterile syringe. The solid samples were taken using sterile equipment (tweezers, hammers, chisels, and spatulas). The samples (pieces of asphalt concrete) were stored in sterile bottles or tubes. The equipment was wrapped in aluminium foil, sterilised via autoclaving, and transported in sterile plastic bags;

- Available components used for the preparation of ACL were taken from quarries: aggregates, sand, and pulverized limestone filler;

- A block of undamaged ACL (approximately $0.1 \mathrm{~m}$ wide $\times 0.1 \mathrm{~m}$ long $\times 0.12 \mathrm{~m}$ deep) was cut from the blister-free part of the lining using a sterilized titanium wheel. In the laboratory, the block was cut into slices with a sterilized disk after $3 \mathrm{~h}$ of pre-warming at $40{ }^{\circ} \mathrm{C}$. Peeled samples of the ACL were taken from the upper face, including the mastic layer, the DAC at depths of 20 and $50 \mathrm{~mm}$, the PAC (one sample), and the interface between the PAC and the drainage layer (back face, one sample). Mastic samples were taken from three different undamaged ACL elevations: one from the upper part of the slope, one from the middle zone subjected to water level fluctuation, and one from the lowest, permanently submerged part of the slope. The last sample was taken when the reservoir was emptied.

Then, the samples were transported to the laboratory for further analysis, which was performed the same or next day. The samples were stored at $4{ }^{\circ} \mathrm{C}$. The samples analysed in this study are summarized in Table 1. 
Table 1. Analysed samples, source, and growth of bacteria in LB medium at different temperatures; detection of PCR products specific for the domain Bacteria.

\begin{tabular}{|c|c|c|c|c|c|c|}
\hline \multirow{2}{*}{ Resource } & \multirow{2}{*}{ Source of Bacteria/Sample } & \multirow{2}{*}{$\begin{array}{c}\text { PCR } \\
\text { Product Detection }\end{array}$} & \multicolumn{4}{|c|}{ Growth $\left({ }^{\circ} \mathrm{C}\right)$} \\
\hline & & & 10 & 30 & 37 & 50 \\
\hline Water & Reservoir & + & + & + & - & - \\
\hline \multirow{4}{*}{$\begin{array}{l}\text { Damaged ACL, } \\
\text { open blister, } \\
\text { inside hole }\end{array}$} & Water & + & + & + & + & + \\
\hline & Asphalt & + & $+\mathrm{g}$ & + & + & + \\
\hline & Asphalt with mastic remnants & + & + & $+\mathrm{g}$ & $+\mathrm{g}$ & $+\mathrm{g}$ \\
\hline & Crumbled aggregate & + & + & + & + & + \\
\hline \multirow{3}{*}{ ACL components } & Aggregates & + & + & + & + & - \\
\hline & Sand & + & + & + & + & + \\
\hline & Pulverized limestone filler & + & + & + & + & - \\
\hline \multirow{5}{*}{$\begin{array}{l}\text { Block of ACL, } \\
\text { blister-free } \\
\text { (undamaged) }\end{array}$} & Upper face with mastic layer & + & + & + & + & + \\
\hline & $20 \mathrm{~mm}$ depth inner portion of DAC & + & - & - & - & - \\
\hline & $50 \mathrm{~mm}$ depth inner portion of DAC & + & - & - & - & - \\
\hline & $100 \mathrm{~mm}$ depth inside of PAC & + & - & - & - & - \\
\hline & Asphalt from PAC layer-back face & + & + & + & - & - \\
\hline \multirow{3}{*}{$\begin{array}{c}\text { Undamaged ACL } \\
\text { mastic, } \\
\text { different } \\
\text { elevations }\end{array}$} & Upper part without reservoir water & + & + & + & + & + \\
\hline & $\begin{array}{l}\text { Middle zone, alternately under and } \\
\text { above water }\end{array}$ & + & + & + & $+\mathrm{g}$ & $+\mathrm{g}$ \\
\hline & $\begin{array}{l}\text { Lowest part, permanently under } \\
\text { water }\end{array}$ & + & + & + & + & $+g$ \\
\hline
\end{tabular}

+—occurrence of phenomenon, - -no growth, g-gas production (bubbles).

\subsection{Isolation of DNA and Polymerase Chain Reaction (PCR)}

Polymerase chain reaction (PCR) was used to confirm the presence of bacterial DNA in the samples. DNA extraction was performed in the following way: sediments of cells were prepared via the centrifugation $(10,000 \times g$ for $5 \mathrm{~min}$.) of water samples and from rinses of solid samples. Approx. $2 \mathrm{~g}$ of solid samples were shaken for approx. $10 \mathrm{~min}$. in $4 \mathrm{~mL}$ of sterile water. Large particles were removed by filtering and the cells in the samples $(4 \mathrm{~mL})$ were centrifuged and treated in $500 \mu \mathrm{L}$ of lysis buffer (10 mM Tris- $\mathrm{HCl} \mathrm{pH} 7.8,5 \mathrm{mM}$ EDTA $\mathrm{pH}$ 8.0, and lysozyme $10 \mathrm{mg} \mathrm{mL}^{-1}$ ) for $1 \mathrm{~h}$ at laboratory temperature. Then, $12.5 \mu \mathrm{L}$ of $20 \%$ SDS and $5 \mu \mathrm{L}$ of proteinase $\mathrm{K}\left(100 \mu \mathrm{g} \mathrm{mL}^{-1}\right)$ were added and incubated at $55{ }^{\circ} \mathrm{C}$ overnight. The DNA was isolated using magnetic poly (2-hydroxyethyl methacrylate-co-glycidyl methacrylate)—P(HEMA-co-GMA) microspheres in the presence of $8.0 \%(w / v)$ poly(ethylene glycol) (PEG 6000) and 2.0 M sodium chloride concentrations [25]. The adsorbed DNA was released from the microspheres in a low ionic strength TE buffer $(10 \mathrm{mM}$ Tris- $\mathrm{HCl} \mathrm{pH} 7.8$ and $1 \mathrm{mM}$ EDTA pH 8.0). The PCR was performed with Feub (TCC TAC GGG AGG CAG CAG T) and Reub (GGA CTA CCA GGG TAT CTA ATC CTG TT) primers specific for the domain Bacteria [26].

Briefly, the PCR mixture contained $1 \mu \mathrm{L}$ of $10 \mathrm{mM}$ dNTP, $1 \mu \mathrm{L}\left(10 \mathrm{pmol} \mu \mathrm{L}^{-1}\right)$ of each primer, $1 \mu \mathrm{L}$

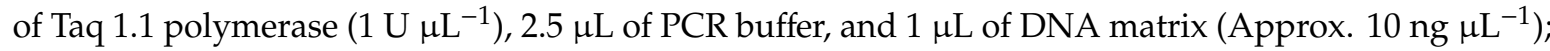
the PCR water was added to reach a volume of $25 \mu \mathrm{L}$. The amplification was carried out using the following cycle parameters: $5 \mathrm{~min}$ of the initial denaturation period at $95{ }^{\circ} \mathrm{C}$ (hot start), $30 \mathrm{~s}$ of denaturation at $95{ }^{\circ} \mathrm{C}, 30 \mathrm{~s}$ of primer annealing at $55^{\circ} \mathrm{C}$, and $30 \mathrm{~s}$ of extension at $72{ }^{\circ} \mathrm{C}$. The DNA amplifications were performed on a Cycler MJ ResearchMini (Bio-Rad, Hercules, CA, USA) according to the standard procedures. The PCR products $(466 \mathrm{bp})$ were detected using agarose gel electrophoresis in $0.5 \times$ TBE buffer ( $45 \mathrm{mM}$ boric acid, $45 \mathrm{mM}$ Tris-base, $1 \mathrm{mM}$ EDTA, $\mathrm{pH}$ 8.0). The agarose gel electrophoresis was carried out using an electrophoresis unit (Bio-Rad). The DNA was stained with 
ethidium bromide $\left(0.5 \mu \mathrm{g} \mathrm{mL} \mathrm{L}^{-1}\right)$, decolorized in water, and observed on an EB-20E UV transilluminator from Ultra Lum (Claremount, CA, USA) at $305 \mathrm{~nm}$ and documented photographically.

\subsection{Cultivation of Bacteria}

Bacteria cultivation was used to analyse the live cells. Bacteria from the analysed water samples

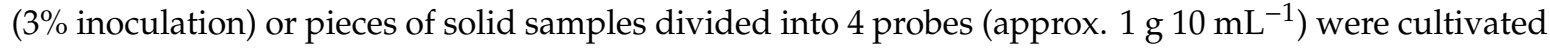
in common bacterial LB medium (Oxoid, London, UK) at four different temperatures: 10, 30, 37, and $50{ }^{\circ} \mathrm{C}$. The growth of the cells in the mixed cultures was monitored over 1-10 days with regard to the turbidity of the liquid media, the creation of sediment, or of a surface membrane. The experiments were repeated twice. Gas production was manifested by the creation of bubbles in the liquid LB medium. The cultures were transferred to LB-agar plates in order to obtain individual bacterial colonies. Colonies of different isolates (morphotypes) were purified via the repeated streaking ( 3 to 4 times) of 1 colony on LB agar and cultivated at $30^{\circ} \mathrm{C}$ for two days for MALDI-TOF MS (Matrix-Assisted Laser Desorption/Ionization-Time of Flight Mass Spectrometry) (Bruker Daltonik, Bremen, Germany) identification and the recognition of bacterial diversity.

\subsection{MALDI-TOF MS Bacteria Identification}

One colony of the purified strain was taken, resuspended in $1000 \mu \mathrm{L}$ of water, centrifuged $(10,000 \times g$ for $3 \mathrm{~min}$ ), and resuspended in $50 \mu \mathrm{L}$ of $75 \%$ ethanol [27]. In some cases (when MALDI-TOF spectra of insufficient quality were achieved), more loopfuls of colonies were collected in $1000 \mu \mathrm{L}$ of water and treated as stated above. For MALDI-TOF MS, the cells sedimented by centrifugation were extracted with $50 \mu \mathrm{L}$ of an acetonitrile/formic acid/water (50:35:15, v/v) mixture by vortexing for $1 \mathrm{~min}$. After centrifugation $(10,000 \times g$ for $2 \mathrm{~min})$, the supernatant was deposited on the stainless-steel sample plate at a volume of $0.3 \mu \mathrm{L}$ and, after drying at room temperature, overlaid with $0.3 \mu \mathrm{L}$ of a saturated alpha-cyano-4-hydroxycinnamic acid solution in an acetonitrile-water-trifluoroacetic acid (50:47.5:2.5, $v / v)$ mixture. MALDI-TOF mass spectra measurements were carried out using an Ultraflextreme instrument (Bruker Daltonik, Bremen, Germany) operated in the linear positive ion mode using FlexControl 3.4 software (Bruker Daltonik, Bremen, Germany).

\subsection{Data Analysis}

The mass spectra were processed using Flex Analysis (version 3.4; Bruker Daltonik, Bremen, Germany) and BioTyper software (version 3.1; Bruker Daltonik, Bremen, Germany). The results of the identification were expressed by BioTyper $\log$ (scores), indicating the similarity of the unknown MALDI-TOF MS profile to available database entries (BioTyper database version 8.0.0.0; Bruker Daltonik, Bremen, Germany). The similarities between the individual mass spectra of the strains and the Biotyper database entries were expressed in the format of log(scores) obtained under the Biotyper software's default settings. Log(score) values greater than 2.000 correspond to species identification with high confidence; $\log$ (score) values between 1.700 and 1.999 to species identification with low confidence; and $\log$ (score) values lower than 1.699 to no identification. If the score difference between the first and second identification hit was lower than 0.1, the result was considered ambiguous. MALDI-TOF mass spectra-based dendrograms were generated using the correlation distance measured with the average linkage algorithm (Unweighted Pair Group Method with Arithmetic Mean-UPGMA) settings and Pearson's correlation coefficient.

\section{Results}

\subsection{Demonstration of Bacterial Presence}

PCR-ready DNA was isolated from the water samples and the rinses of the hard samples and amplified (without cultivation). Amplicons specific for the domain Bacteria (466 bp) were detected using agarose gel electrophoresis. The results are given in Figure 3. It was confirmed that bacterial 
DNA (from both live and dead cells) was present in all samples. Bacteria isolated from the tested samples were cultivated, purified, and used for MALDI-TOF MS identification. We analysed 104 different colonies taken from the different sources that were cultured under the conditions applied (Table 1).

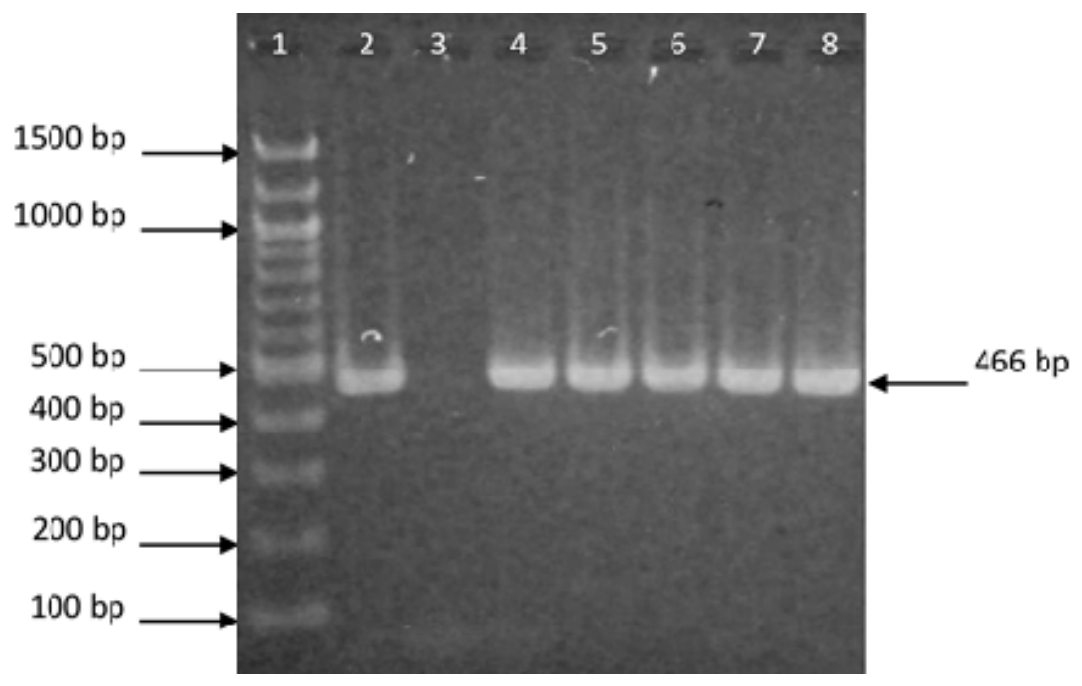

Figure 3. Agarose gel electrophoresis of the PCR products specific for the domain Bacteria (466 bp). DNA was isolated from the water and the rinsed solid samples taken from the open blisters. Lanes: 1-DNA marker (100 bp ladder); 2-10 ng DNA from Lacbacillus spp. (positive control); 3-negative control (no DNA); 4-water from the reservoir; 5-water from the open blister; 6-asphalt; 7-asphalt with mastic remnants; and 8 -crumbled aggregate.

The bacteria isolated from the reservoir water grew at 10 and $30{ }^{\circ} \mathrm{C}$ (Table 1 ), but they did not grow at 37 and $50{ }^{\circ} \mathrm{C}$. This was in contrast with the growth exhibited by the bacteria isolated from the water from inside the hole of an open blister (see below). They were classified into seven morphotypes (Table 2, Group I). Two morphotypes were identified as unique species of the genus Pseudomonas (P. chlororaphis and P. fragi); 4 of the others were placed into the genus Pseudomonas (species identification ambiguous) and one isolate remained without identification.

Table 2. Source of the bacteria, the number of morphotypes in the bacterial colonies, genus and species (unique and ambiguous) identification, and the number of non-identified morphotypes.

\begin{tabular}{|c|c|c|c|c|c|c|}
\hline Resource & $\begin{array}{c}\text { Source of } \\
\text { Bacteria/Group }\end{array}$ & $\begin{array}{l}\text { Morpho } \\
\text { Types }\end{array}$ & $\begin{array}{c}\text { Genus } \\
\text { Identification }\end{array}$ & $\begin{array}{c}\text { Species } \\
\text { Identification/ } \\
\text { No. of Strains }\end{array}$ & $\begin{array}{l}\text { Ambiguous } \\
\text { Identification/ } \\
\text { No. of Strains }\end{array}$ & $\begin{array}{c}\text { Without } \\
\text { Identification/ } \\
\text { No. of } \\
\text { Strains }\end{array}$ \\
\hline Water & Reservoir/I & 7 & Pseudomonas & $\begin{array}{c}\text { P. chlororaphis } \\
\text { P. fragi }\end{array}$ & Pseudomonas (4) ${ }^{\mathrm{a}}$ & 1 \\
\hline \multirow{4}{*}{$\begin{array}{c}\text { Damaged } \\
\text { ACL, open } \\
\text { blister, inside } \\
\text { hole }\end{array}$} & Water/II & 11 & Pseudomonas & P.chlororaphis (4) & Pseudomonas (5) ${ }^{\mathrm{b}}$ & 2 \\
\hline & Asphalt/III & 11 & $\begin{array}{l}\text { Pseudomonas } \\
\text { Bacillus }\end{array}$ & $\begin{array}{c}\text { P. koreensis } \\
\text { B. cereus } \\
\text { B. thuringiensis }\end{array}$ & $\begin{array}{c}\text { Pseudomonas (2) } \\
\text { Bacillus (1) }\end{array}$ & 6 \\
\hline & $\begin{array}{l}\text { Asphalt with } \\
\text { mastic } \\
\text { remnants/IV }\end{array}$ & 12 & $\begin{array}{c}\text { Pseudomonas } \\
\text { Bacillus } \\
\text { Lysinibacillus } \\
\text { Staphylococcus }\end{array}$ & $\begin{array}{c}\text { B. licheniformis } \\
\text { L. fusiformis } \\
\text { L. boronitolerans }(4.9 \\
\text { g) } \\
\text { S. xylosus }\end{array}$ & $\begin{array}{l}\text { Pseudomonas (4) d1 } \\
\text { Lysinibacillus (1) } \mathrm{d} 2\end{array}$ & $4(4.10 \mathrm{~g})$ \\
\hline & $\begin{array}{c}\text { Crumbled } \\
\text { aggregate/V }\end{array}$ & 19 & $\begin{array}{l}\text { Pseudomonas } \\
\text { Bacillus } \\
\text { Lysinibacillus } \\
\text { Staphylococcus } \\
\text { Rhodococcus } \\
\text { Micrococcus }\end{array}$ & $\begin{array}{c}\text { P. koreensis } \\
\text { B. subtilis } \\
\text { L. fusiformis (2) } \\
\text { S. equorum (2) } \\
\text { S. warneri } \\
\text { R. erytropolis (5) } \\
\text { M. luteus }\end{array}$ & Pseudomonas (1) $\mathrm{e}$ & 6 \\
\hline
\end{tabular}


Table 2. Cont

\begin{tabular}{|c|c|c|c|c|c|c|}
\hline Resource & $\begin{array}{c}\text { Source of } \\
\text { Bacteria/Group }\end{array}$ & $\begin{array}{c}\text { Morpho } \\
\text { Types }\end{array}$ & $\begin{array}{c}\text { Genus } \\
\text { Identification }\end{array}$ & $\begin{array}{l}\text { Species } \\
\text { Identification/ } \\
\text { No. of Strains }\end{array}$ & $\begin{array}{l}\text { Ambiguous } \\
\text { Identification/ } \\
\text { No. of Strains }\end{array}$ & $\begin{array}{l}\text { Without } \\
\text { Identification/ } \\
\text { No. of } \\
\text { Strains }\end{array}$ \\
\hline \multirow{3}{*}{$\begin{array}{c}\text { ACL } \\
\text { components }\end{array}$} & Aggregates/VI & 4 & $\begin{array}{l}\text { Pseudomonas } \\
\text { Bacillus } \\
\text { Lysinibacillus }\end{array}$ & $\begin{array}{l}\text { P. chlororaphis } \\
\text { B. licheniformis } \\
\text { L. fusiformis }\end{array}$ & & 1 \\
\hline & Sand/VII & 9 & $\begin{array}{l}\text { Pseudomonas } \\
\text { Lysinibacillus } \\
\text { Aeromonas }\end{array}$ & $\begin{array}{c}\text { P. chlororaphis } \\
\text { P. frederiksbergenesis } \\
\text { L. sphaericus } \\
\text { L. fusiformis (3) } \\
\text { A. salmonicida }\end{array}$ & Pseudomonas (2) ${ }^{\mathrm{f} 1}$ & \\
\hline & $\begin{array}{l}\text { Pulverized } \\
\text { limestone } \\
\text { filler/VIII }\end{array}$ & 2 & Bacillus & & Bacillus (2) ${ }^{\mathrm{f} 2}$ & \\
\hline \multirow{2}{*}{$\begin{array}{l}\text { Block of ACL, } \\
\text { blister-free } \\
\text { (undamaged) }\end{array}$} & $\begin{array}{l}\text { Upper face with } \\
\text { mastic layer/IX }\end{array}$ & 4 & Bacillus & $\begin{array}{l}\text { B. licheniformis (2) } \\
\text { B. pumilus }\end{array}$ & & 1 \\
\hline & $\begin{array}{l}\text { Asphalt from } \\
\text { PAC layer back } \\
\text { face/X }\end{array}$ & 3 & $\begin{array}{l}\text { Microbacterium } \\
\text { Micrococcus }\end{array}$ & $\begin{array}{c}\text { M. } \\
\text { hydrocarbonooxydans } \\
(2) \\
\text { M. luteus }\end{array}$ & & \\
\hline \multirow{3}{*}{$\begin{array}{l}\text { Undamaged } \\
\text { ACL mastic, } \\
\text { different } \\
\text { elevations }\end{array}$} & $\begin{array}{l}\text { Upper part } \\
\text { without } \\
\text { reservoir } \\
\text { water/XI }\end{array}$ & 2 & & & & 2 \\
\hline & $\begin{array}{c}\text { Middle zone, } \\
\text { alternately } \\
\text { under and } \\
\text { above water/XII }\end{array}$ & 16 & $\begin{array}{c}\text { Bacillus } \\
\text { Staphylococcus }\end{array}$ & $\begin{array}{l}\text { B. licheniformis (2) } \\
\text { B. cereus } \\
\text { B. pumilus } \\
\text { S. equorum (3) }\end{array}$ & & $9(8.11 \mathrm{~g})$ \\
\hline & $\begin{array}{c}\text { Lowest part, } \\
\text { permanently } \\
\text { under water/XIII }\end{array}$ & 4 & Bacillus & $\begin{array}{l}\text { B. thuringiensis (2) } \\
\quad(8.2 \mathrm{~g}, 8.3 \mathrm{~g})\end{array}$ & & $2(8.1 \mathrm{~g})$ \\
\hline
\end{tabular}

Ambiguous identification-identified as members of more than one species. ${ }^{a} P$. rhodesiae/P. gessardi/P. antarctica, $P$. gessardi/P. rhodesiae/P. proteolytica, $P$. teatrolens $/ P$. fragi/P. lundensis, $P$. teatrolens $/ P$. fragi; ${ }^{b}$ P. corrugata/P. chlororaphis $/ P$. thivervalensis/P. chlororaphis/P. corrugate, $P$. chlororaphis/P. thivervalensis, $P$. fragi/P. teatrolens, $P$. chlororaphis/P. kilonensis, $P$. chlororaphis/P. corrugate; ${ }^{c 1}$ P. rhodesiae/P. antarctica, P. rhodesiae/P. antarctica/P. grimontii; ${ }^{c 2}$ B. altitudinis/B. pumilus; ${ }^{d 1}$ P. rhodesiae/P. trivialis/P. gessardii, P. rhodesiae/P. tolaasii/P. antarctica, P. antarctica/P. tolaasii/P. fluorescens, P. corrugata/P. jessenii; ${ }^{d 2}$ L. fusiformis/L. boronitolerans; ${ }^{e}$ P. chlororaphis/P. jeseni; ${ }^{\prime 1}$ P. brassicarum/P. kilonensis, P. fredericksbergensis/P. mandelii; f2 B. thuringiensis/B. cereus; g: gas production; S: Staphylococcus; R: Rhodococcus; M: Micrococcus; P: Pseudomonas; B: Bacillus; L: Lysinibacillus; A: Aeromonas.

Bacteria cells isolated from the components used for the asphalt concrete lining's production (aggregates, sand, and pulverized limestone filler) were grown at all temperatures, with the exception of those from the aggregates and pulverized limestone filler, in which bacteria did not grow at $50{ }^{\circ} \mathrm{C}$ (Table 1). They formed 15 morphotypes on solid media (Table 2, Groups VI-VIII). The bacteria detected were of the genus Pseudomonas (P. chlororaphis and P. frederiksbergensis, two strains with ambiguous identification), Bacillus (B. licheniformis, two strains with ambiguous identification), Lysinibacillus (L. fusiformis and L. sphaericus), and Aeromonas (A. salmonicida), while one strain from the aggregates was not identified.

\subsection{Cultivation and Identification of Bacteria from the Undamaged $A C L$}

Some parts of the surface were without apparent damage (blister-free). Bacteria were cultivated from the upper face of the block with the mastic layer at all temperatures, and from the PAC of the back face at 10 and $30^{\circ} \mathrm{C}$. No bacteria were cultivated from inner portions (at depths of 20, 50, and $100 \mathrm{~mm}$ ) of the block without damage at any tested temperature (Table 1). The bacteria from the upper face with its mastic layer were grown in 4 morphotypes. These were identified as being of the genus Bacillus ( 2 strains of B. licheniformis and 1 strain of B. pumilus), while 1 strain was not identified. The bacteria in the back face (3 morphotypes) were identified as being of the genus Microbacterium ( 2 strains of 
the species M. hydrocarbonooxydans) and Micrococcus (1 strain of the species M. luteus); see Table 2, Groups IX and X.

The results of the cultivation of bacteria from mastic scraped from the undamaged ACL at different elevations are shown in Table 1 . The bacteria grew at all the tested temperatures, as did the bacteria from the open blister. The bacteria from the middle and lowest parts of the slope produced gas at 37 and $50{ }^{\circ} \mathrm{C}$. The bacterial presence in the mastic differed depending on its location. The mastic from the upper part of the slope with no contact with the reservoir water contained few bacterial species: only 2 morphotypes were grown, and these remained without identification (Table 2, Group XI). The mastic from the middle zone of the slope, which was alternately in contact with circulating water and exposed to air, was relatively rich in different bacteria. Among the 16 morphotypes found, 4 were classified into the genus Bacillus (B. licheniformis-2 strains, B. cereus and B. pumilus) and 3 into the genus Staphylococcus (S. equorum), while altogether 9 morphotypes remained without identification with regard to genus (Table 2, Group XII). One non-identified (NoID) strain (8.11) produced gas. The mastic in the lowest part of the slope (4 morphotypes) contained gas-producing bacteria of the genus Bacillus (B. thuringiensis-2 strains, 8.2 and 8.3) and two non-identified strains (8.1, a gas producer) (Table 2, Group XIII).

\subsection{Cultivation and Identification of Bacteria from the Damaged ACL}

The defects in the ACL were manifested by the creation of thousands of local blisters for reasons which remain unknown. The blisters were of different sizes and shapes, and were discovered practically all around the peripheral dam, though their intensity varies. Newly formed blisters were closed, but they opened up as they developed. The closed blisters bulged slightly without any apparent cracks or openings visible from the surface of the lining. Cells present in the damaged ACL were taken from the open blisters (which contained water, asphalt, asphalt with mastic remnants, and crumbled aggregate) and cultivated. The bacteria grew at all of the temperatures tested (Table 1). Altogether, 53 different morphotypes were isolated.

The bacteria isolated from the water (Table 2, Group II) were classified into 11 morphotypes, nine of which were identified as members of the genus Pseudomonas (4 of the species P. chlororaphis, and 5 of ambiguous species in which the spectra enabled genus identification). Two morphotypes were not identified.

The bacteria from the solid samples grew in 42 morphotypes. The most complex bacterial compositions were found on the asphalt (11 morphotypes), asphalt with mastic remnants (12 morphotypes), and crumbled aggregate (19 morphotypes) (Table 2, Groups III-V). They were classified into 6 genera (Pseudomonas, Bacillus, Lysinibacillus, Staphylococcus, Rhodococcus, and Micrococcus) and 12 species. A total of 9 morphotypes were identified in terms of genus only (ambiguous species identification), whereas 16 morphotypes have yet to be identified. The high bacterial diversity is demonstrated in the dendrogram in Figure 4. 


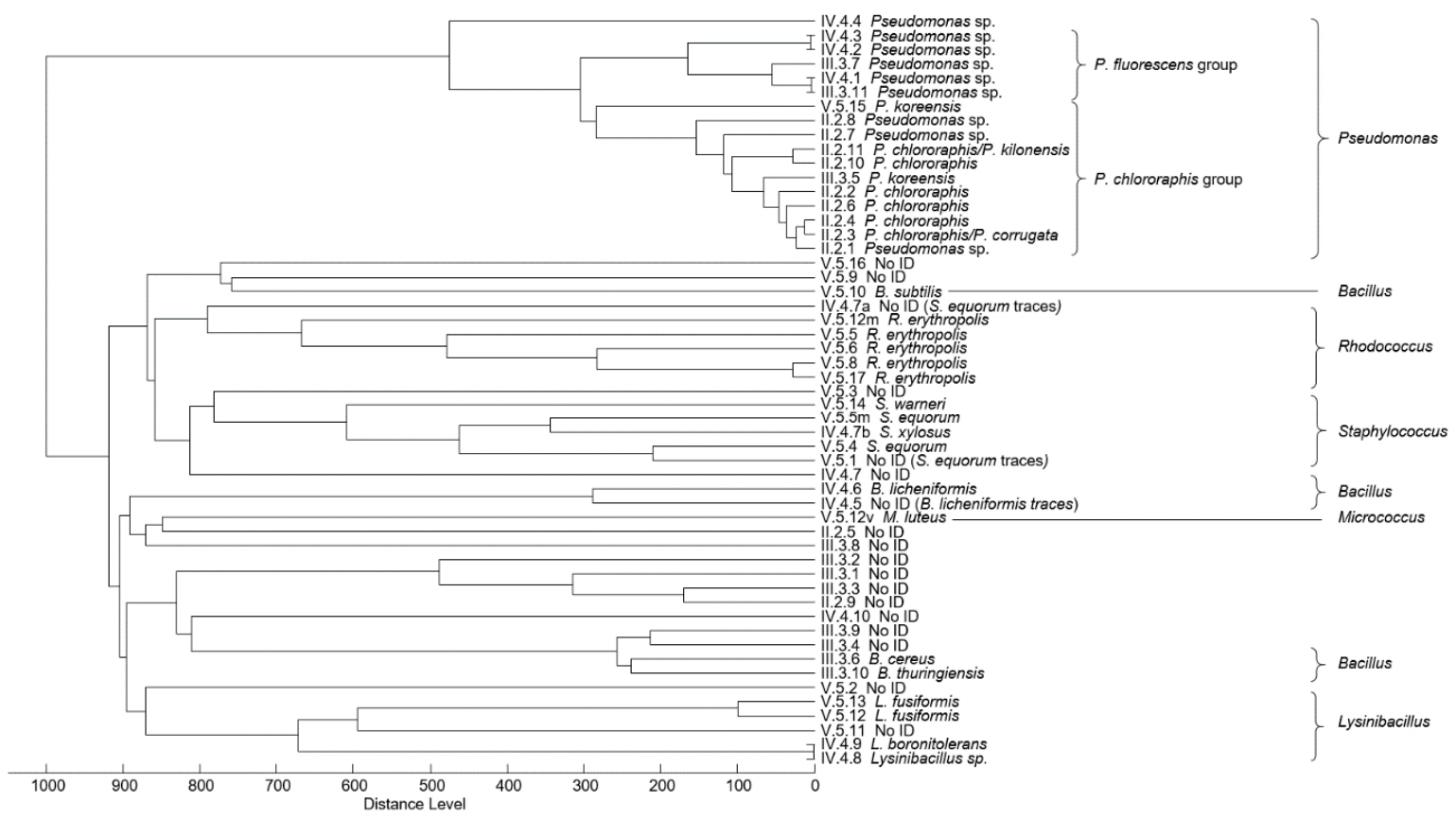

Figure 4. Dendrogram of the bacterial strains isolated from the open blisters (Groups II, III, IV, and V). The dendrogram was generated by MALDI-TOF MS patterns using UPGMA analysis and Pearson's correlation coefficient. NoID-without identification.

\section{Discussion and Conclusions}

\subsection{Bacterial Strain Identification}

The presence of microorganisms is generally expected in all water reservoirs, including those sealed with an ACL. Individual bacterial species usually grow in specific types of colonies (morphotypes). However, sometimes one species forms different colonies. This phenomenon was described for Rhodococus erythropolis [28]. The identification of some species using MALDI-TOF MS is complicated as there are no corresponding spectra in the database. Unidentified strains formed multiple groups on the dendrogram, which implies that there is diversity among them. In addition, some closely related species, such as Pseudomonas spp., cannot be distinguished due to the high degree of similarity between their mass spectra, and so were identified in terms of genus only.

\subsection{Identification of Bacteria from the Undamaged ACL}

Some parts of the surface of the lining were without apparent damage (blister-free). The undamaged ACL mastic was analysed at different elevations. Only two strains were isolated from the mastic from the upper part of the slope, the section which has no contact with the water. According to the authors of [5], there were no blisters in the parts above the water level of the reservoir they studied. A larger number of morphotypes (altogether 16, covering 2 different genera and 4 species) were isolated from the middle part, which is alternately under water and exposed to air. The mastic coating is exposed to wet/dry cyclic conditions in this case. No growing bacteria were isolated from the inner parts of the block of undamaged, blister-free ACL. During the construction of the power plant, the ACL and mastic were mixed, transported, and placed at temperatures that were higher than $140{ }^{\circ} \mathrm{C}$ for approximately 3 to $4 \mathrm{~h}$ or more. Therefore, it is supposed that most of the bacteria that were present in the components of the ACL (aggregates, sand, and limestone filler) were killed and therefore not cultivated. Thus, the use of hot mixtures should be preferred when choosing lining repair and mastic renovation techniques.

Spore-forming bacteria of the genus Bacillus, which can survive hot conditions, were cultivated from the mastic from the upper face of the blister-free block. It cannot be excluded that the 
M. hydrocarbonooxydans and M. luteus strains cultivated from the back face of the PAC layer originated from the period when the reservoir was reconstructed some years ago. Both of these species are known to use oil for their growth $[29,30]$.

\subsection{Identification of Bacteria from the Damaged ACL}

The bacteria isolated from the water in the open blisters exhibited a higher diversity of morphotypes (different species of the genus Pseudomonas, 11 morphotypes) compared to the bacteria isolated from the reservoir water (other species of the genus Pseudomonas except one, 7 morphotypes). This is probably influenced by the presence of different substrates in the tested water samples.

The blistering occurred in the middle zone of the ACL, which was subjected to reservoir water fluctuation. Bacterial diversity in the damaged ACL (open blisters) was higher (53 morphotypes) in comparison with the blister-free parts (22 morphotypes). The most complex bacterial population was found on the crumbled aggregate (6 different genera and 8 species) and on the asphalt with mastic remnants (4 different genera and 6 species). The predominant genera of the asphalt-degrading bacteria are the genera Pseudomonas, Chromobacterium, and Bacillus [16], or Pseudomonas, Acinetobacter, Alcaligenes, Flavimonas, and Flavobacterium [17]. Bacterial genera Pseudomonas, Bacillus, Lysinibacillus, and Staphylococcus were identified in samples taken from inside the blisters from the water, asphalt, asphalt with mastic remnants, and crumbled aggregates (Table 2). Bacterial species commonly found in soil are Bacillus cereus (Gram-positive, facultatively anaerobic, motile, and spore forming) [31], Bacillus thuringiensis (Gram-positive, aerobic, and spore-forming) [32], Bacillus licheniformis (Gram-positive, facultatively anaerobic, and spore-forming) [33], Bacillus subtilis (Gram-positive, facultatively anaerobic, motile, and spore-forming) [34], Pseudomonas koreensis (Gram-negative, non-spore-forming, and motile) [35], Pseudomonas chlororaphis (Gram-negative, aerobic, motile, and non-spore-forming) [36], Staphylococcus xylosus (Gram-positive, aerobic to facultatively anaerobic, non-spore-forming, and forms clusters of cells) [37], Lysinibacillus boronitolerans (Gram-positive, spore-forming, and motile) [38], Lysinibacillus fusiformis (Gram-positive, motile, and spore-forming) [39], and Micrococcus luteus (Gram-positive to Gram-variable, obligate aerobic, non-spore-forming, and non-motile) [40]. In contrast with the bacterial strains isolated from natural asphalt sources, which were anaerobic, the abovementioned bacteria are facultatively anaerobic or aerobic [19]. According to the literature [28,41-45], all bacterial genera identified in this work in the investigated blisters (Pseudomonas, Bacillus, Lysinibacillus, Staphylococcus, Rhodococcus, and Micrococcus) contain species that degrade polycyclic hydrocarbons/oil/asphalt. Bacteria of the genera Pseudomonas, Bacillus, and Rhodococcus show the ability to degrade and transform a wide variety of natural organic compounds via diverse catabolic pathways [24,44,46,47]. Some acids produced by microorganisms [18] may react with aggregate components and produce gas, too. According to the authors of [14], gases produced by microorganisms can disturb the asphalt overlay material. Asphalt can act as a substrate for certain bacteria that can degrade it directly [16-22]. Other bacteria can survive and utilize the decomposition products of degrading bacteria. The production of biosurfactants is a common mechanism that enables bacteria to solubilise viscous oils [28,48-50]. The solubility of asphalt is important for bacteria that use it as source of nutrition. This solubility is enhanced by increases in temperature. Some of the bacterial strains isolated from the open blisters were spore forming, allowing them to survive extreme environmental conditions with regard to temperature. Individual species are of course part of the mixed microbial consortia (microbial community) at high cell densities [19]. Although individual microorganisms have mechanisms for hydrocarbon degradation, other species may aid in this process via symbiotic relationships [51,52]. Some papers have reported the important role of a bacterial consortium composed from Pseudomonas and Rhodococcus [53,54].

The bacterial species Bacillus cereus [31], Bacillus subtilis [34], Pseudomonas koreensis [35], Pseudomonas chlororaphis [36], Lysinibacillus boronitolerans [38], and Lysinibacillus fusiformis [39] were motile with swarming growth. Swarming growth can support the spread of non-motile bacteria involved in consortia [55]. The microorganisms that are present in the open blisters do not automatically have a 
specifically related function there. Thus, it can be stated that the study of bacterial activities will lead to a better understanding of the process of open blister evolution and ACL destruction.

The transfer of bacteria from the reservoir water and environment (e.g., air, rainwater, or snow) as well as the climate should be taken into consideration. The relatively quick appearance of blisters in summer could be attributed to the enhanced activity of bacteria at higher temperatures. This consideration could explain why visible differences in blister formation occur in different parts of the perimeter lining. According to the authors of [13], water and air enter through cracks caused by the shrinkage of the overlay during the cold season. The blisters rise and crack (burst) during the warm season as a result of the softening of the asphalt binder and the stresses created by the expansion of the pavement matrix caused by air and moisture. It can be assumed that the opening of a blister allows microorganisms to attack it and participate in its degradation. For this reason, great care must be taken during the production of asphalt concrete linings. This statement agrees with the recommendation of the authors of [5].

The results presented here show that bacterial diversity in the damaged ACL (open blisters) was much higher in comparison with the blister-free undamaged parts of the ACL (mastic) in the zone of water level fluctuation. The bacterial genera that were isolated from the open blisters (water, asphalt, asphalt with mastic remnants, and crumbled aggregates) occur in all environments around the world. Hence, the obtained results reflect the importance of the study of bacterial diversity in blisters and the possible role of such bacteria in ACL degradation. In future research, special attention should be paid to the study of bacterial activities, and specifically those of bacteria with catabolic pathways for the degradation of petroleum hydrocarbons. In particular, from a practical point of view, special attention should also be paid to the procedures used in the production of ACLs.

Author Contributions: Methodology, investigation, M.Š.; conceptualisation, J.̌̌.; bacteria cultivation, isolation and purification of individual morphotypes, DNA isolation and PCR, A.Š.; identification of the bacterial strains (isolates) using MALDI-TOF, formal analysis, O.Š.; writing—original draft preparation, B.R. All authors have read and agreed to the published version of the manuscript.

Funding: This paper was prepared under project TH04020154 (Optimization of the construction, repairs and performance of asphaltic concrete linings) from the Technology Agency of the Czech Republic. Financial support from project MSM 0021622415 from the Ministry of Education, Youth, and Sports of the Czech Republic as well as from internal grant FCH-S-14-2325 from Brno University of Technology is gratefully acknowledged. The work was also supported by European Regional Development Fund Project "CIISB4HEALTH" (No. CZ.02.1.01/0.0/0.0/16_013/0001776). The authors would also like to thank CIISB, the Instruct-CZ centre of the Instruct-ERIC EU consortium funded by MEYS CR infrastructure project LM2018127, for the financial support provided for the measurements conducted at the CEITEC Proteomics Core Facility.

Acknowledgments: The authors would like to thank Miroslava Gregerová from the Department of Geological Sciences at the Faculty of Science at Masaryk University in Brno for providing the impetus to deal with the role of microorganisms in blister formation. Thanks also to Roger Turland for his work in reviewing this paper from a language perspective.

Conflicts of Interest: The authors declare no conflict of interest.

\section{References}

1. Swiss National Committee on Large Dams (SNCOLD). Longterm Behaviour of Bituminous and Cement Concrete Facings of Compensation Reservoirs in Switzerland; Question No. 61, R. 18; VII International Commission on Large Dams (ICOLD): San Francisco, CA, USA, 1988; pp. 311-325.

2. Schonian, E. The Shell Bitumen Hydraulics Engineering Handbook; CD ROM Version; Thomas Telford: London, UK, 1999.

3. Ǩ́íha, J.; Buchtová, J. The asphalt and geomembrane dam lining database and its use at the Dlouhe Strane dam rehabilitation. In Proceedings of the Dams at the Beginning of the 21st Century, Annual Dresden Conference on Hydraulic Engineering, Dresden, Germany, 10-11 March 2005; Dresdner Wasserbauliche Mitteilungen: Dresden, Germany, 2005; pp. 277-286, ISBN 3-86005-461-9.

4. Grätz, B.; Klimke, H.D.; Mock, P.; Seibert, C. Blasenbildung beim gussasphalt-einbau. einflussgrősse hohlraumgehalt der asphaltbinderschicht. Asphalt Jungle 2011, 46, 15-25. 
5. Wang, Z.; Hao, J.; Sun, Z.; Ma, B.; Xia, S.; Li, X. Blistering mechanism analysis of hydraulic asphalt concrete facing. Appl. Sci. 2019, 9, 2903.

6. Adam, K.; Říha, J.; Špano, M. Investigation on the temperature of the asphalt-concrete facing of embankment dams. Int. J. Pav. Res. Technol. 2016, 9, 73-81.

7. Sobolewski, T. PGE Energia Odnawialna SA; Monografia Elektrowni Szczytowo-Pompowej Porabka Žar Wydanie II: Biala, Polska, 2010.

8. Akhtarpour, A.; Khodaii, A. Experimental study of asphaltic concrete dynamic properties as an impervious core in embankment dams. Constr. Build. Mater. 2013, 41, 319-334.

9. Liu, H.; Yuan, G.; Zhang, Q.; Hao, P.; Dong, S.; Zhang, H. Study on influence factors of asphalt mixtures pavement blistering on Portland cement concrete bridge deck. Int. J. Pavement Eng. 2019. [CrossRef]

10. Garcia-Gil, L.; Miró, R.; Pérez-Jiménez, F.E. Evaluating the role of aggregate gradation on cracking performance of asphalt concrete for thin overlays. Appl. Sci. 2019, 9, 628. [CrossRef]

11. Teltayev, B.B.; Rossi, C.O.; Izmailova, G.G.; Amirbayev, E.D. Effect of freeze-thaw cycles on mechanical characteristics of bitumens and stone mastic asphalts. Appl. Sci. 2019, 9, 458. [CrossRef]

12. Croll, J.A. A new hypothesis for the development of blisters in asphalt pavements. Int. J. Pavement Eng. 2008, 9, 59-67.

13. Hironaka, M.C.; Holland, T.J. Blistering of Asphalt Pavement Overlay on Runway 14-32 at MCAS; NCEL Technical Note N-1744; NCEL: Beaufort, SC, USA, 1986.

14. Brown, L.R.; Darnell, T.R. Factors Affecting the Microbial Deterioration of Asphalt Overlays; Final Report to Mississippi State Highway Department; Report NO. MSHD-RD-86-84; Federal Highway Administration: Washington, DC, USA, 1986; p. 43.

15. Brown, L.R.; Darnell, T.R. Blistering of asphalt overlays caused by microorganisms. J. Assoc. Asphalt Paving Technol. (AAPT) 1987, 56, 361-380.

16. Phillips, U.H.; Traxler, R.W. Microbial degradation of asphalt. Appl. Microbiol. 1963, 11, $235-238$.

17. Pendrys, J.P. Biodegradation of asphalt cement-20 by aerobic bacteria. Appl. Environ. Microbiol. 1989, 55, 1357-1362.

18. Koul, S.; Fulekar, M.H. Petrochemical industrial waste: Bioremediation techniques. Int. J. Adv. Res. Technol. 2013, 2, 211-257.

19. Kim, J.S.; Crowley, D.E. Microbial diversity in natural asphalts of the Rancho La Brea Tar Pits. Appl. Environ. Microbiol. 2007, 73, 4579-4591. [CrossRef]

20. Balcon, I.N.; Crowley, D.E. Microbial diversity of asphalt-soil mixtures in the Rancho LA Brea asphalt seeps. Int. J. Phytoremediat. 2015, 12, 599-615.

21. Hernández-López, E.L.; Ayala, M.; Vazques-Duhalt, R. Microbial and enzymatic biotransformation of asphaltenes. Pet. Sci. Technol. 2015, 33, 1017-1029. [CrossRef]

22. Ghosal, D.; Ghosh, S.; Dutta, T.K.; Ahn, Y. Current state of knowledge in microbial degradation of polycyclic aromatic hydrocarbons (PAHs): A Review. Front. Microbiol. 2016, 7, 1369. [PubMed]

23. Hesham, A.E.-L.; Alamri, S.A.; Khan, S.; Mahmoud, M.E.; Mahmoud, H.M. Isolation and molecular genetic characterization of a yeast strain able to degrade petroleum polycyclic aromatic hydrocarbons. Afr. J. Biotechnol. 2009, 8, 2218-2223.

24. Lawal, A.T. Polycyclic aromatic hydrocarbons. A review. Cogent Environ. Sci. 2017, 3, 1339841.

25. Španová, A.; Rittich, B.; Štyriak, I.; Štyriaková, I.; Horák, D. Isolation of polymerase chain reaction-ready bacterial DNA from Lake Baikal sediments by carboxyl-functionalised magnetic polymer microspheres. J. Chromatogr. A 2006, 1130, 115-121. [CrossRef]

26. Haarman, M.; Knol, J. Quantitative real-time PCR analysis of fecal Lactobacillus species in infants receiving a prebiotic infant formula. Appl. Environ. Microbiol. 2006, 72, 2359-2365.

27. Freiwald, A.; Sauer, S. Phylogenetic classification and identification of bacteria by mass spectrometry. Nat. Protoc. 2009, 4, 732-742. [CrossRef]

28. Peng, F.; Liu, Z.; Wang, L.; Shao, Z. An oil-degrading bacterium: Rhodococcus erythropolis strain 3C-9 and its biosurfactants. J. Appl. Microbiol. 2007, 102, 1603-1611. [CrossRef]

29. Schippers, A.; Bosecker, K.; Sproer, C.; Schumann, P. Microbacterium oleivorans sp. nov. and Microbacterium hydrocarbonoxydans sp. nov., novel crude-oil-degrading Gram-positive bacteria. Int. J. Syst. Evol. Microbiol. 2005, 55, 655-660. [CrossRef] [PubMed] 
30. Golby, S.; Ceri, H.; Gieg, L.M.; Chatterjee, I.; Marques, L.L.R.; Turner, R.J. Evaluation of microbial biofilm communities from an Alberta oil sands tailing pond. FEMS Microbiol. Ecol. 2012, 79, 240-250. [CrossRef] [PubMed]

31. Stenfors Arnesen, L.P.; Fagerlund, A.; Granum, P.E. From soil to gut: Bacillus cereus and its food poisoning toxins. FEMS Microbiol. Rev. 2008, 32, 579-606. [CrossRef] [PubMed]

32. Sauka, D.H.; Basurto-Ríos, R.E.; Ibarra, J.E.; Benintende, G.B. Characterization of an Argentine isolate of Bacillus thuringiensis similar to the HD-1 strain. Neotrop. Entomol. 2010, 39, 767-773. [CrossRef] [PubMed]

33. Gallegos-Monterrosa, R.; Kankel, S.; Götze, S.; Barnett, R.; Stallforth, P.; Kovács, Á.T. Lysinibacillus fusiformis M5 induces increased complexity in Bacillus subtilis 168 colony biofilms via hypoxanthine. J. Bacteriol. 2017, 199, e00204-17. [CrossRef]

34. van Dijl, J.M.; Hecker, M. Bacillus subtilis: From soil bacterium to super-secreting cell factory. Microb. Cell Fact. 2013, 12, 3. [CrossRef]

35. Kwon, S.W.; Kim, J.S.; Park, I.C.; Yoon, S.H.; Park, D.H.; Lim, C.K.; Go, S.J. Pseudomonas koreensis sp. nov., Pseudomonas umsongensis sp. nov. And Pseudomonas jinjuensis sp. nov., novel species from farm soils in Korea. Int. J. Syst. Evol. Microbiol. 2003, 53, 21-27. [CrossRef]

36. Calderón, C.E.; Ramos, C.; de Vicente, A.; Cazorla, F.M. Comparative genomic analysis of Pseudomonas chlororaphis PCL 1606 reveals new insight into antifungal compounds involved in biocontrol. Mol. Plant Microbe Interact. 2015, 28, 249-260. [CrossRef]

37. Keskin, N.O.S.; Han, D.; Ozkan, A.D.; Angun, P.; Umu, O.C.O.; Tekinay, T. Production and structural characterization of biosurfactant produced by newly isolated Staphylococcus xylosus STF1 from petroleum contaminated soil. J. Petrol. Sci. Eng. 2015, 133, 689-694. [CrossRef]

38. Ahmed, I.; Yokota, A.; Yamazoe, A.; Fujiwara, T. Proposal of Lysinibacillus boronitolerans gen. nov. sp. nov., and transfer of Bacillus fusiformis to Lysinibacillus fusiformis comb. nov. and Bacillus sphaericus to Lysinibacillus sphaericus comb. nov. Int. J. Syst. Evol. Microbiol. 2007, 57, 1117-1125. [CrossRef]

39. Josic, D.; Porobic, M.; Milicevic, M.; Vukovic, D.; Pivic, R.; Zdravkovic, M.; Coric, T. RAPD fingerprinting of indigenous Lysinibacillus fusiformis isolates from stabilized sludge and oil-polluted soil. In Proceedings of the 6th International Meeting on Soil Fertility Land Management and Agroclimatology, Kusadasi-Aydin, Turkey, 29-31 October 2008; pp. 927-933.

40. Tuleva, B.; Christova, N.; Cohen, R.; Antonova, D.; Todorov, T.; Stoineva, I. Isolation and characterization of trehalose tetraester biosurfactants from a soil strain Micrococcus luteus BN56. Process Biochem. 2009, 44, 135-141. [CrossRef]

41. Ting, A.S.Y.; Tan, H.C.; Aw, C.S. Hydrocarbon-degradation by Isolate Pseudomanas lundensis UTAR FPE2. Malays. J. Microbiol. 2009, 5, 104-108.

42. Das, N.; Chandran, P. Microbial degradation of petroleum hydrocarbon contaminants: An overview. Biotechnol. Res. Int. 2011, 211, 1-13. [CrossRef] [PubMed]

43. Basu, B.; Ramasamy, R.; Viswanathan, S.; Priya, I.D.; Jeyan, J.; Reddy, A.; Kumar, V.V. Analysis of aromatic hydrocarbon degrading capacity by thermophilic bacteria isolated from oil contaminated soil. Int. J. ChemTech Res. 2014, 6, 4556-4563.

44. Rabus, R.; Boll, M.; Heider, J.; Meckenstock, R.U.; Buckel, W.; Einsle, O.; Ermler, U.; Golding, B.T.; Gunsalus, R.P.; Kroneck, P.M.; et al. Anaerobic microbial degradation of hydrocarbons. From enzymatic reactions to the environment. J. Mol. Microbiol. Biotechnol. 2016, 26, 5-28. [CrossRef]

45. Filatov, D.; Kopytov, M.; Ovsyannikova, V.; Elchaninova, E. Microbial oxidation of high viscosity bitumen in soil. Eurasian Chem. Technol. J. 2018, 20, 159-169. [CrossRef]

46. Vinithini, O.; Sudhakar, S.; Ravikumar, R. Biodegradation of petroleum and crude oil by Pseudomonas putida and Bacillus cereus. Int. J. Curr. Microbiol. Appl. Sci. 2015, 4, 318-329.

47. Kim, D.; Choi, K.Y.; Yoo, M.; Zylstra, G.J.; Kim, E. Biotechnological potential of Rhodococcus biodegradative pathways. J. Microbiol. Biotechnol. 2018, 28, 1037-1051. [CrossRef]

48. Olowomofe, T.O.; Oluyege, J.O.; Aderiye, B.I.; Oluwole, O.A. Degradation of poly aromatic fractions of crude oil and detection of catabolic genes in hydrocarbon-degrading bacteria isolated from Agbabu bitumen sediments in Ondo State. AIMS Microbiol. 2019, 5, 308-323. [CrossRef]

49. Bento, F.M.; de Oliveira Camargo, F.A.; Okeke, B.C.; Frankenberger, W.T. Diversity of biosurfactant producing microorganisms isolated from soils contaminated with diesel oil. Microbiol. Res. 2005, 160, $249-255$. [CrossRef] [PubMed] 
50. Patowary, K.; Patowary, R.; Kalita, M.C.; Deka, S. Characterisation of biosurfactant produced during degradation of hydrocarbons using crude oil as sole source of carbon. Front. Microbiol. 2017, 8, 279. [CrossRef] [PubMed]

51. Soare, M.G.; Lakatos, E.S.; Ene, N.; Malo, N.; Popa, O.; Băbeanu, N. The potential applications of Bacillus sp. and Pseudomonas sp. strains with antimicrobial activity against phytopathogens, in waste oils and the bioremediation of hydrocarbons. Catalysts 2019, 9, 959. [CrossRef]

52. Truskewycz, A.; Gundry, T.D.; Khudur, L.S.; Kolobaric, A.; Taha, M.; Aburto-Medina, A.; Ball, A.S.; Shahsavari, E. Petroleum hydrocarbon contamination in terrestrial ecosystems fate and microbial responses. Molecules 2019, 24, 3400. [CrossRef] [PubMed]

53. Vaidya, S.; Jain, K.; Madamwar, D. Metabolism of pyrene through phthalic acid pathway by enriched bacterial consortium composed of Pseudomonas, Burkholderia, and Rhodococcus (PBR). Biotechnology 2017, 7, 29. [CrossRef]

54. Dasgupta, D.; Jublee, J.; Suparna, M. Characterization, phylogenetic distribution and evolutionary trajectories of diverse hydrocarbon degrading microorganisms isolated from refinery sludge. Biotechnology 2018, 8, 273. [CrossRef]

55. Hagai, E.; Dvora, R.; Havkin-Blank, T.; Zelinger, E.; Porat, Z.; Schulz, S.; Helman, Z. Surface-mobility induction, attraction and hitchhiking between bacterial species promote dispersal on solid surfaces. ISME J. 2014, 8, 1147-1151. [CrossRef]

Publisher's Note: MDPI stays neutral with regard to jurisdictional claims in published maps and institutional affiliations.

(C) 2020 by the authors. Licensee MDPI, Basel, Switzerland. This article is an open access article distributed under the terms and conditions of the Creative Commons Attribution (CC BY) license (http://creativecommons.org/licenses/by/4.0/). 